\title{
Functional Discounts Under the Robinson-Patman Act
}

\author{
Richard S. Kelley*
}

\begin{abstract}
A $N$ UNDERSTANDING of the economic impact of the Robinson-Patman A Act $^{1}$ on the distributive trades is impossible without full realization of the significant differences between functional and trade discounts. The terms "trade discount" and "functional discount" are often used synonomously. A trade discount is normally defined as a price differential granted by the seller to a particular buyer dependent on, and because of, the supplier's classification of the buyer at a level of commodity distribution. ${ }^{2}$ For example, a wholesaler is allowed a larger discount than a retailer.

The discount granted to manufacturers from that price charged other consumers is sometimes characterized as a trade discount. ${ }^{3}$ This usage is not consistent with the above defimition. Both the day to day purchaser of yard goods at the local dry goods store and the manufacturing tailor are consumers and thus on the same level of commodity distribution. Neither resells the cloth as cloth. The discount the manufacturing tailor receives from the price charged the day to day purchaser is a functional and not a trade discount. The terms are not synonomous.

A functional discount is a broader concept than a trade discount. It is defined for the purposes of this paper as the differential in price extended by a seller to a buyer who, because of the buyer's performance of distributive functions or elimination of the need for the performance thereof by the character of his buying, is possessed of greater bargaining power than other buyers. Whereas trade discounts are based on traditional classifications with not too accurate a regard for actual functions performed, functional discounts are based on bargaining power of buyers regardless of any arbitrary classification of the buyer.
\end{abstract}

*Assistant Professor of Law, Creighton University.

149 STAT. 1526 (1936), 15 U.S.C. $\$ 13$ (1946). Section 1 of the Robinson-Patman Act amended section 2 of the Clayton Act, 38 StAT. 730 (1914), 15 U.S.C. $\$ 13$ (1946), by dividing it into six lettered parts, which will be referred to in this article as sections 2(a) through (f) of the Robinson-Patman Act.

2 Rowe says of trade discounts, "The seller's schedule fixes discounts from quoted price to buyers classified according to rank on the distribution ladder." Rowe, Price Discrimintationt, Competition and Confusion: Another Look at Robinson-Patman, 60 YALE L. J. 929, 932 (1951). Van Cise says that "Functional prices are in essence 'status' prices. They distinguish between customers-not on the basis of size, or cost savings, or location-but solely because of their differing roles in the distribution, processing, and consumption of commodities." Van Ciso, Functional Prices, CCH Robinson-Patman Act Sympostum 89 (1947).

3 Manufacturers are best thought of, for analytical purposes, as consumers performing no distributive function, since they do not resell goods in the form in which they buy them. However, manufacturers often receive greater discounts than those allowed wholesalers. These discounts are allowed because of the buyer's great bargaining power and the seller's cost savings on bulk sales. 
The economics of the distributive trades cannot be arbitrarily determined by rigid classifications of customers by level of distribution. ${ }^{4}$ When customers possess bargaining power resulting from their methods of purchase, suppliers stand ready to make price concessions. Classification becomes irrelevant. Thus industrial consumers often are granted lower prices than wholesalers, since the nature of their purchasing eliminates traditional wholesalers and accompanying costs. ${ }^{5}$ Examples of distributive costs which particular buyers sustain, eliminate, or partially eliminate include advertising, transportation, storage, and sales promotion.

The capital risks involved in performing distributive functions can also be borne in whole or in part by buyers. Retailers who also perform wholesale functions possess the bargaining power necessary to obtain functional discounts from retailer list prices.

No intimation is intended that the discount allowed the buyer performing or eliminating distributive functions is necessarily equal to the $\cos ^{6}$ savings resulting to the seller. If that were true, there would be no economic price discrimination, which exists only when disproportionately lower prices are charged some buyers, relative to the product-service exchanged. ${ }^{*}$

\section{Integration and Discounts}

The problem of price discrimination is mescapably related to vertical integration. Producers, by integration downward, perform distributive functions normally performed by wholesalers and retailers. ${ }^{8}$ Economic efficiencies can result, since joint performance of functions can lower some costs and eliminate others. ${ }^{9}$ The same efficiencies are possible through upward intergration by retailers.

Without availability of functional discounts, upward integration would lose its appeal. Retailers integrating upward by performing wholesale functions and incurring the incident costs would hardly be content with retail

4 "One of the pronounced characteristics of present day marketing is the degree to which familiar designations such as wholesaler, retailer, broker, manufacturer's sales branch, fail to describe institutions which as a class perform similar functions." Teele, Logics and Emotions in Marketing in REAdiNgs IN MARKeting 314, 318 (McNair and Hansen ed. 1949).

5 See, e.g., Baran v. Goodyear Tire and Rubber Co., 256 Fed. 571 (S.D.N.Y. 1919); S. S. Kresge Co. v. Champion Spark Plug Co., 3 F.2d 415 (6th Cir. 1925); Champion Spark Plug Co., FTC Docket No. 3977 (pending).

6 "Cost" is used here in the economic sense to include a normal profit, and not in the accounting sense of the sum total of expenditures.

7 "Technically, then, price discrimination may be defined as unequal treatment of those with whom a buyer or seller has had dealings by making a disproportionately lower price to some than to others relative to the product service exchanged." Cassady, Some Economic Aspects of Price Discrimination under Non-Profit Market Conditions, 11 J. Markstarg 7, 9 (1946).

8 Vertical integration makes producers, wholesalers, and retailers all potential competitors of each other. While distributive middlemen are eliminated, overall competition is improved. The greatest danger hes in the possibility that buyers, by integration, will become powerful enough to upset the market, but the relative ease of entry into the distributive trades makes this unlikely. When and if such power is found to exist, the Sherman Act would seem the best tool for restoring the necessary balance.

${ }^{9}$ Spreading overhead costs and fuller utilization of by-products or collateral activity lowers costs, and distribution to oneself avoids selling or "transfer" costs. See Adelman, Integration and Antitrust Policy, 63 HaRv. L. Rev. 27, 29 (1949). 
list prices. Such retailers, under the theory of trade discounts, remain classified as retailers and consequently pay retail prices. Clearly, no inducement to integrate wholesale and retail functions exists if retailer list prices must be paid by the integrated purchaser.

An integrated purchaser must convince the Federal Trade Commission that any discount accorded hin from the price to a non-integrated purchaser is justified by seller savings. This burden of proof creates risks which discourage distributional innovations. Further, the Robinson-Patman Act provides that purchasers cannot receive discounts for performing or eliminating the brokerage function, even though such a practice results in seller savings. ${ }^{10}$

Trade discounts granted traditional single function wholesalers or retailers not attempting to integrate across distributional classification lines of commerce have for the most part escaped FTC condemnation and need not be justified under the cost savings proviso. ${ }^{11}$ This policy allows competition only within lines of commerce and not across them.

\section{Price Discrimination under the Robinson-Patman Act}

Economists include within the tern "costs" an amount characterized as a "normal profit."12 Accountants, on the other hand, exclude such a figure froin costs and define profit as the difference between gross income and total expenses. ${ }^{13}$ The cost savings proviso of the Robinson-Patman Act does not seem to show a proper understanding of the above distinctions, for differentials in prices between buyers are allowed only to the extent of provable seller's savings in expenditures.

Suppliers selling direct to retailers will normally be performing the wholesale function with its attendant costs. Such suppliers normally earn a profit for performing this function. The differential between prices charged wholesalers and retailers should reflect not only the savings in expenditure of serving the two classes of purchasers, but also the profit. When suppliers do not perforin the wholesale function (as when they sell to wholesalers), legally restricting the differential between wholesale and retail prices to cost savings in the accounting sense arbitrarily grants profits to suppliers they do not earn and deprives wholesale buyers of margins normally necessary

10 See Great Atlantic \& Pacific Tea Co. v. FTC, I06 F.2d 667 (3rd Cir. 1939), cert. denied, 308 U.S. 625 (1940).

11 The first proviso under $\$ 2$ (a) of the Robinson-Patman Act, supra note 1, reads: "Provided, that nothing herein contained shall prevent differentials which make only due allowance for differences in the cost of manufacture, sale, or delivery resulting from the differing methods or quantities in which such commodities are to such purchasers sold or delivered." See list of cases cited 81 Cong. REc. APP. 10, 2338 passim. But cf. Standard Oil Co. v. FTC, 173 F. 2 d 210 (7th Cir. 1949), rev'd on other grounds, 340 U.S. 231 (1951), modified, CCH TRADE REg. REP. (9th ed.) II 14,925.40 (FTC 1952).

12 "[It] also implies that full costs include a 'normal' return, or free market reward to all factors, including owner's investment and management, and thus includes a 'normal profit' to the firm." Bann, Pricrng Distribution and EMplayment 64 (1948).

13 Accounting costs are distinguished from economic costs in Mason, Fundanentals of Accounrivo 224 (1947). 
to earn profits by performance of the wholesale function. The same argument is applicable to retailers performing wholesale functions. To avoid economic price discrimination, the Act should at least allow the price to vary in terms of economic, not accounting, terms of cost.

It seems apparent that the Act is not all that supporters of competition might desire. Criticisms have been many with respect to both its deterrent effect on competition and to its ambiguous and inept phraseology. ${ }^{14}$ The Robinson-Patman Act ${ }^{15}$ and its parent, the Clayton Act, ${ }^{16}$ must be analyzed in the light of specific situations raising functional discount problems to determine the validity or invalidity of these criticisms.

\section{Functional Discounts under the Clayton Act}

Neither the Robinson-Patman Act nor its predecessor, the Clayton Act, mentions functional discounts or trade discounts by name. A logical assumption would seem to follow: Under either act, the validity of functional discounts or trade discounts will depend, not on their characterization as such, but instead, on the prohibitive effect of the legislation on price discrimination in general. Section 2 of the Clayton Act, before amendment, provided:

That it shall be unlawful for any person ... to discriminate in price between different purchasers ... where the effect of such discrimination may be to substantially lessen competition or tend to create a monopoly in any line of commerce: Provided, that nothing herein contained shall prevent discrimination in price between purchasers ... on account of differences in the grade, quality, or quantity . . . sold, or that makes only due allowance for difference in the cost of selling or transportation, ... And provided further, that nothing herein contained shall prevent persons . . . from selecting their own customers in bonafide transactions and not in restraint of trade.

Two reasons have been advanced for finding trade discounts immune from the prohibitions of Section 2. First, trade discounts could be justified within the proviso that different buyers could be charged different prices depending solely on quantities purchased which price differences were not limited to cost savings resulting from the varying quantities sold. The argument ran as follows: Trade discounts granted distributive middlemen were

\footnotetext{
${ }^{14}$ See, e.g., "We sympathize with the petitioner's position and can realize the difficulties of conducting business under such general prohibitions. Nevertheless, we are convinced that the cause of the trouble is the [Robinson-Patman] Act itself, which is vague and general in its wording and which cannot be translated with assurance into any detailed set of guiding yardsticks." Clark, J., in Ruberoid Co. v. FTC, 189 F.2d 893, 894 (2d Cir. 1951); "There is no occasion to dwell on the ambiguities of the Robinson-Patman Act.... The result [of conflicting interests] was a practical rather than a logical accommodation ... to assure its passage. Couple that background with poor draftsmanship, and the ugly contours of one of the most difficult interpretive problems presented by a major legislative enactment are exposed." Schniderman, The Tyranny of Labels, 60 HARv. L. Rev. 571 (1947). Contrast Oppenheim, Should the Robinson-Patman Act be Amended?, CCH Robinson-Patman Act Sympostum 141, 143 (1948).

15 Supra note 1.

16 Supra note 1.
} 
quantity discounts. Quantity discounts were unlimited. ${ }^{17}$ Ergo, trade discounts were unlimited. This was not a sound argument for the validity of trade discounts under the Clayton Act, since distributive middlemen traditionally received their trade discount regardless of the quantity purchased. Furthermore, the Robinson-Patman amendment now places a cost savings limit on quantity discounts, thus clothing them with the same status as other price differentials. No longer can the characterization of a trade discount as a quantity discount give it a status different from other price differentials.

Secondly, it was argued that their effect was not "to substantially lessen competition or tend to create a monopoly in any line of commerce," since the buyers involved were not in competition with each other. The argument supporting this second reason is somewhat complicated. In Mennen Co. v. $F T C,{ }^{18}$ an FTC order which would have prohibited different prices to purchasers, dependent on their classification as wholesalers or retailers, ${ }^{10}$ was overruled. The FTC findings showed that large numbers of retailers had banded together to make group purchases for their individual members. ${ }^{20}$ Mennan Company refused to sell to such groups at wholesale prices. ${ }^{21}$ Since the individual retailers were selling to consumers, Mennen classified the groups as retailers and charged them retailer prices. Under the order, Mennen Co. could no longer differentiate in price between customers purchasing goods of like quantity and quality solely on the basis that these customers belonged to different levels of commodity distribution. The court, in overruling the order, held that price discrimination between buyers belonging to different classifications in the level of distribution did not have the effect of substantially lessening competition or tending to create a monopoly in any line of commerce within the meaning of the Clayton Act. ${ }^{22}$ This conclusion followed from the proposition that the prohibition of practices substantially lesseming competition or tending to create a monopoly in any line of commerce was restricted to the discriminating seller's (Mennen)

17 Goodyear Tire and Rubber Co. v. FTC, 101 F.2d 620 (6th Cir. 1939), cert. denied, 308 U.S. 557 (1939). This case, though decided after adoption of the Robinson-Patman amendment, was governed by the terms of the Clayton Act due to the saving clause (\$2) of the RobinsonPatman Act.

18288 Fed. 774 (2d Cir. 1923), cert. denied, 262 U.S. 759 (1923).

18 Mennen was ordered to "cease and desist from discrimmating in net selling prices, by any method or device, between purchasers of the same grade, quality and quantity of commodities, upon the basis of a classification of its customers as 'jobbers', 'wholesalers', or 'retailers', or any similar classification which relates to the customers' form of organization, business policy, business methods, or to the business of the customers' membership or shareholders in any transaction in, or directly affecting interstate commerce, in the distribution of its products." The Mennen Co., 4 F.T.C. 258, 283 (1922).

$20 I d$, at 279.

21 Id. at 281 .

22 "The record filed in the court shows no contention by the Commission that the practices complained of have lessened competition as hetween the Mennen Company and its competitors, but it shows at the most that the practices have decreased competition among the Mennen Company's customers, or those desiring to become such." Rogers, J., in Mennen Co. v. FTC, supra note 18 at 778. "... [T] of the section mere competition among 'purchasers' from the 'seller' or 'person' who allowed or withheld the discount and to include therem only competition between such 'seller' or 'person' and the latter's own competitors." Id. at 779. 
level of competition. A dictum in the decision indicated that even had the court considered the lessening of competition among buyers to be a violation of the Act, the buyers involved were on different levels of competition, one group being wholesalers and the other retailers, so no harm to buyer competition resulted. ${ }^{23} \mathrm{~A}$ further dictum approved classification of buyers based on the character of their sales rather than the character of their purchases. ${ }^{24}$

These two dicta gained substantial importance by virtue of an indirect broadening of the prohibitory terms of the Clayton Act in George Van Camp \& Son v. American Can $\mathrm{Co}^{25}$ to include practices lessening competition among buyers. Supporters of the validity of trade discounts under the Clayton Act could cite the dicta in Mennen to sustain price differentials granted buyers traditionally classified at different levels of distribution, ${ }^{26}$ despite the holding in Van Camp.

It should be noted that the FTC, not the reviewing court, was the champion of functional discounts as distinguished from trade discounts in the Mennen case. The FTC was interested in seeing purchasers who perforined wholesale functions receive wholesale prices regardless of their traditional classification as retailers. ${ }^{27}$ The court, on the other hand, struck a blow at functional discounts by refusing to admit the possibility that performance of wholesale functions by purchasers, traditionally classified as retailers, would entitle such purchaser to wholesale discounts. Thus, while decreeing the doom of functional discounts, the court protected trade or "status" discounts.

Two other cases often have been cited as sustaining the validity of trade discounts. Baron v. Goodyear Tire and Rubber $\mathrm{Co}^{28}$ and S. S. Kresge Co. v. Champion Spark Plug 29 both upheld the validity of a price differential between retailers and inanufacturers. Both might be said to involve "trade discounts in reverse," for in each case manufacturing consumers were granted larger discounts than retailers who were performing a distributive function not performed by the manufacturing consumer. The differentials were held not violative of the Clayton Act since the contrasted buyers

23 "There is nothing unfair in declining to sell to retailers on the same scale of prices it sold to wholesalers, even though the retailers bought or sought to buy the same quantity the wholesalers bought." Id. at 781 .

24 "Whether a buyer is a wholesaler or not does not depend upon the quantity he buys. It is not the character of his buying, but the character of his selling, which marks him as a wholesaler...."Id. at 782. On the other hand, from the functional point of view, a wholesaler is allowed a lower price than the ordinary retailer because the former performs the services of warchousing and of distribution in small quantities. Adelman, supra note 8, at 29.

25278 U.S. 245 (1929).

20 Traditionally classified in terms of selling, not buying, characteristics, under their argument.

27 Though the FTC order in Mennen was broad enough to imply the outlawry of both trade and functional discounts, the facts of the case indicate that the FTC was interested not only in preserving functional discounts, but in forcing suppliers to grant wholesaler's discounts to retailers performing wholesale functions.

28 Supra note 5 .

29 Supra note 5. 
(manufacturers and retailers), regardless of their relative standing in the level of distribution, were not competing with each other.

These two cases actually are definite support for the validity of functional discounts. Unless the theory of trade discounts can be stretched to include the giving of a larger discount to consumers than that allowed retailers, these cases hardly can be argued in support of the granting of trade discounts. It is unfortunate that the court chose to rest its decision on the non-competing character of the buyers, failing to recognize that it was the character of the buying which enabled the seller to grant manufacturers lower prices than granted retailers.

Robinson-Patman amendments to the Clayton Act now forestall the complete Mennen escape for trade discounts by extending the prohibition of price differentials to dealers situated in different levels of competition. A trade discount, which would not contravene the prohibitions of the Clayton Act because the respective purchasers were on different levels of competition, may still violate Robinson-Patman, for now price differentials that "injure, destroy, or prevent competition with any person who either grants or knowingly received the benefit of such discrimination or with customers of either of them" (emphasis added) are prohibited..$^{30}$

Both trade $^{31}$ and functional ${ }^{32}$ discounts were sustained by the courts under the Clayton Act on the grounds that since the buyers did not compete with each other, competition was not imjured, destroyed, or prevented. Robinson-Patman amendments now prevent the use of this argument.

The orignial bill introduced by Representative Patman, when reported out to the House, contained specific exemptions for trade discounts to purchasers classified by their sellimg function and included an exemption for the type of functional discount normally extended to manufacturers over other consumers..$^{33}$ However, the Robinson-Patman Act as finally enacted omitted both exemptions and the classification test. ${ }^{34}$

\section{Robinson-Patman Additions and Changes to the Clayton Act}

The Robmson-Patman Act became law in 1936 at a time when economic conditions, if not at critical depression level, were, nevertheless, far from prosperous. The Act reflects the temper and even the hysteria ${ }^{36}$ of the times.

3049 STAT. 1526 (1936), 15 U.S.C. \$13(a) (1946).

31 Mennen Co. v. FTC, supra note 18 . The actual reason for sustaining the discounts was not the non-competing character of the buyers, but, dicta indicated, had the Clayton Act prohibited practices injuring coinpetition between buyers, the court would have reached the same conclusion on this alternative ground.

32 Baran v. Goodyear Tire and Rubber Co., supra note 5 ; S. S. Kresge Co. v. Champion Spark Plug, supra note 5.

33 H. R. REP. No. 2287, 74th Cong., 2d Sess. 1-2 (1936).

34 The Conference Comnnittee without explanatory comments, ehminated all reference to any functional or trade discount exemptions or methods of classifying purchasers. H. R. REP. No. 2951, 74th Cong., 2d Sess. 1, 6 (1936).

35 Debate in Congress reveals extreme emotional outbursts. "Yes; let us strike. Remember you are striking for your child and your grandchild that he may have the opportunity that you and $I$ had before the damnable chains came into existence in this country (applausel)." Statement by Mr. Shannon (Missouri), 80 CoNG. REC. 8129 (1936); "No chain store in my coininunity has ever carried the widow Jones or her two kids on their books for 30 or 60 days ... while she was getting together a few pennies to pay for the things which she had to buy from the store." Mr. Nichols (Okla.), id. at 8135. 
While it would be unfair to say that it was not carefully considered prior to passage ${ }^{36}$ powerful special interests ${ }^{37}$ were responsible for its very wording. ${ }^{38}$ Economists' statements at the time of its passage, erroneously used in support of the Act, ${ }^{39}$ were really opposed to its provisions as tending to reduce that competition the Sherman Act ${ }^{40}$ was intended to protect. ${ }^{41}$ This is not to say that the Act's supporters ${ }^{42}$ were against competition. Instead, they forcefully argued that the Act would prevent monopolies in their incipiency. ${ }^{43} \mathrm{It}$ is, however, suggested that those who were conscientious supporters of the Act had not reached the point of economic sophisitication that would allow them to see the fundamental difference between protection of competitors and maintenance of competition. ${ }^{44}$ They argued strongly that efficiencies in the distributive system would not be penalized. ${ }^{45}$ Later discussion will show how false this conclusion proved to be.

36 The two original bills, H.R. 8442 and S. 3154, 74th Cong., 1st Sess. 9 (1935) were considered at length by the committees to which they were referred. Long hearings were conducted. Extensive debate on the bills in both House and Senate resulted in various amendments. Conference Committee changes were significant, and two sessions of Congress considered the various bills and amendments before final passage of the Robinson-Patman Act.

37 Some groups vitally concerned with the provisions of the Act were a wholesale grocers association whose counsel, Mr. Teegarden, authored the original bill, The National Grange, certain co-operative organizations, National Association of Food Brokers, and other farm groups. For an excellent discussion of those interests involved see Ellison, Robinson-Patman Act-Its Political and Commercial Background in Conference Proceedings on RobinsonPatacan Anti-Discrimination Act 4 (1936).

38 Congressman Patman admitted in hearings before the House Judiciary Committee that Mr. H. B. Teegarden, counsel for the U.S. Wholesale Grocers Association, wrote the bill that Patman introduced into the House. Hearings before the House Judiciary Committee on H.R. 8442 , 74th Cong., 1st Sess. 9 (1935).

39 Numerous economists' statements made in reference to strengthening of the antitrust program of the Democratic party's platform in the presidential election in 1932 were cited in the majority report of H.R. 8442 , supra note 36 , when recommending its passage. Comments accompanying the statements clearly implied that such statements supported the economic principles inherent in the bill. H. R. Rep. No. 2287, 74th Cong., 2d Sess. 4-6 (1936).

4026 STAT. 209 (1890), 15 U.S.C. $\$ 1$ (1946).

41 Representative Cellar in his accompanying minority report cited numerous communications from these same economists remonstrating at the use of their name in support of a bill which they felt undermined the basic philosophy of the Sherman Act. Minority H. R. Rep. No. 2287, 74th Cong., 2d Sess. 7-11 (1936).

42 This is not meant to include those special interest groups who specifically lobbied for provisions protecting their "vested rights."

43 The giving or receiving of a price discrimination was considered a tactic of the budding monopolist. Since in either case he might not be as yet a monopolist, the Act in prohibiting the practice would avoid the necessity for proof of intent to monopolize required by the Sherman Act.

44 Corwin Edwards, now Chief Economist for the FTC, writes, " . . to avoid that result [that the Robinson-Patman Act will destroy competition] injury, to coinpetition should be defined as the injury to the vitality of competition in the market, not as injury to competition between particular designated competitors nor as injury to a particular competitor, even though the power of large buyers is somewhat less drastically reduced by such an interpretation." Edwards, Matntaming Compretition 168 (1949). See also, "The cases' undercurrent of protecting some competitors, however, increasingly conflicts with public policy of competition itself." Rowe, supra note 2 at 942.

45 The House Judiciary Committee in recommending passage reported: "There is nothing in it [the proposed bill, H. R. 8442] to penalize, shackle, or discourage efficiency, or to reward inefficiency ...." Any physical economies that are to be found in mass buying and distribu- 
The form and substance of the Robinson-Patman Act was a result of a series of conflicting ideas and interests. Some thought the evil to be eliminated was selling below cost; ${ }^{46}$ others were primarily interested in plugging the unlimited quantity discount and meeting competition gaps in the Clayton Act; ${ }^{4 i}$ still others saw advertising allowances which exceed value received as the major evil $;^{48}$ and from the all inclusive prohibitory terms of Section 2(c), it is easy to see that many were concerned only with maintaining their position im the distributive system. ${ }^{49}$ Attempts to write in specific exemptions for trade discounts failed. ${ }^{50}$ An attempt to define the criteria for determining the classification of customers also fell by the wayside. ${ }^{51}$ Blanket exemption for price systems founded on the basing point method was defeated, yet a provision defining "price" which would have compelled F.O.B. pricing was also rejected by Congress. ${ }^{52}$ The net result has proved to be a headache to the business man and his legal adviser, ${ }^{53}$

tion, whether by corporate chain, voluntary chain, mail order house, department store, or by the cooperative grouping of producers, wholesalers, retailers, or distributors-and whether those economies are .... from the elimination of unnecessary salesmen, . . . unnecessary truck or other forms of delivery, or other such causes-none of them are in the remotest degree disturbed by the bill." H. R. Rep. No. 2287, 74th Cong., 2d Sess. 17 (1936).

46 Section 3 of the Act, commonly called the Borah-Van Nuys section, reflecting the integration of their bill (S.1171) into the basic Patman Bill (H.R.8442), reads in part: "It shall be unlawful ... to sell or contract to sell goods at unreasonably low prices for the purpose of destroying competition or eliminating a competitor." 49 STAT. 1526 (1936), 15 U.S.C. § 13 (a) (1946). Sales below costs would imply unreasonably low prices.

47 After discussing the prohibitions in the Clayton Act the House Judiciary Committec report noted: "The Clayton Act, however, contained the following provisos: Provided, that nothing herein contained shall prevent discrimination in price ... on account of differences ... in ... quantity ... sold, ... or discriminations in price ... made in good faith to meet com. petition." "These provisos have so materially weakened section 2 of that Act, which this bill proposes to amend, as to render it inadequate, if not almost a nullity." H. R. REP. No. 2287, 74th Cong., 2d Sess. 7 (1936).

48 "Still another favored medium for the granting of oppressive discriuninations is found in the practice [of granting] ... advertising and other sales-promotional services . . . . Such an allowance becomes unjust when the service is not rendered as agreed and paid for, or when, if rendered the payment is grossly in excess of its value." Id., at 15.

49 Much discussion of the brokerage section centered on elimination of "dummy or secret" brokerage, yet the wording of the section is not limited in any way to such prohibitions. See statements by Patman and others. 80 Cong. Rec. 7759-7760 (1936).

50 The Conference Committee eliminated the provision providing specific exemptions. See note 34 supra.

- 51 Ibid.

52 The definition read: "That the word 'price' as used in section 2 shall be construed to mean the amount received by the vendor after deducting freight or other transportation, if any, allowed or defrayed by the vendor." This amendment, first added to the Patman bill by the House Judiciary Committee, was withdrawn after House opposition to it developed. See 80 Cono. Rec. 8182, 8140, 8224 (1936).

53 See $e . g$., critical comments on the vagueness and ambiguities of the Act, Austern, Required Competitive Injury and Permitted Meeting of Competition, CCH RoBINson-Patman Acr Sraposionr 63 (1947); ". . . it would be arrogant even to attempt to catalog the wide valleys of confusion-and the deep gullies of complete uncertainty-in which lurk the double headed dragons of Commission action and treble damage suits." Austern, Inconsistencies in the Law, Business Practices under Federal Antitrust Laws, CCE Robinson-Patman ACt SyarpoSrUM 164 (1951). Cf. statement in Judiciary Committee report on H.R. 8442 (Patman bill) "No business institution need have any fear of this legislation if it will conduct its business honestly and without the use of unfair trade practices, and unjust price discriminations." H.R. REP. No. 2287, 74th Cong., 2d Sess. 17 (1936). 
grounds for strong sentiments by a member of the Act's administering body, ${ }^{54}$ a barrier to modernization of methods of distribution, ${ }^{55}$ perpetuation of economic price discrimination, ${ }^{50}$ and a green light for an imposing series of treble damage actions. ${ }^{57}$

Section 2(a) has successfully plugged the unlimited quantity discount loophole of the original Clayton Act. ${ }^{58}$ Less success has been effected by the attempt to close off the "meeting competition" defense. ${ }^{59}$ But the most significant portions of the Robinson-Patman Act within the theme of this paper are the sandbags it added to the top of the levee and not the ones it threw in the holes. By giving the kiss of death to price discriminations whose effect "may be [substantially] to injure, destroy, or prevent coinpetition with any person who either grants or knowingly receives the benefit of such discrimination, or with customers of either of them", the Act places serious limitations on trade and functional discounts. By singling out brokerage allowances as cost savings that cannot be reflected in lower prices to those buyers makmg such savings possible, the Act produces economic price discrimination, and without economic justification, prohibits a form of functional discount.

\section{ROBINSON-PATMAN IMPACT ON MARKETING METHODS}

A complete knowledge of modern marketing methods is unnecessary for an understanding of Robinson-Patman's application to specific transactions. ${ }^{\circ 0}$ The accompanying simplified diagram provides an adequate visual approach to available supplier choices for distributing his product to ultimate consumers. It portrays only those fundamental relations necessary to an understanding of Robinson-Patman Act implications of the validity of

54 Speaking of $\$ 2$ (c) of the Act in a recent concurring opinion, Commissioner Mason writes, "And Congress had commanded that a manufacturer's intermediary cannot be under the direct or indirect control of the huyer. To give a high moral tone to this mandate, it is said that in law as well as in morals, a man cannot serve two masters. A more inept application could hardly be found, for in the American business scene, the merchant serves not one, but thousands of masters if lie would succeed .... But to make doubly sure that an intermediary employed by a manufacturer didn't serve the retailer, we are here enforcing a law which in effect decrees that a certain cut of the housewife's grocery dollar must go as a broker's gabelle or else be pocketed by the manufacturer limself rather than have it seep down to aid either grocer or consumer." CCH TRADE REg. REP. (9th ed.) II 14,925.27 (1952).

65 Ibid. See also discussion of Sherwin Williams case and Standard Oil case in the text infra at note 90 , et seq.

56 See discussion of Bird case in the text infra at note 123, et seq.

6r See long list of cases cited in Rowe, supra note 2 at $940 \mathrm{n.65}, 941 \mathrm{n.73}$ (1951).

ES FTC v. Morton Salt Co., 334 U.S. 37 (1948) (quantity discounts not justified under the cost proviso were disallowed).

50 It has been argued that placing the "meeting competition" defense in $\$ 2(\mathrm{~b})$ converted it from substantive to procedural. See discussion of pros and cons, McCollester, Section 2(b), CCH Robinson-Patiman Act Symposion 23 (1946). The problem was settled in favor of a substantive defense by Standard Oil Co. v. FTC, supra note 11. Many problems of interpretation remain. For two comprehensive discussions, see Rose, The Right of a Businessman to Lover the Price of His Goods, 4 VAND. L. Rev. 221 (1951); Simon, Price Discrimination to Meet Competition, [1950] U. of IrL. L. ForuM 575 (1951).

60 For a inore complete coverage of the problems, see e.g., Agnew and Hougliton, MarkerIng Policies cc. 3, 4, 5 and 6 (2d ed. 1951); Maynard, Weidler and Beckman, PrIncIPLes of Marketivg c. 18 (3d ed. 1939); McNair and Hansen, Readings IN Marketing 266-358 (1949). 


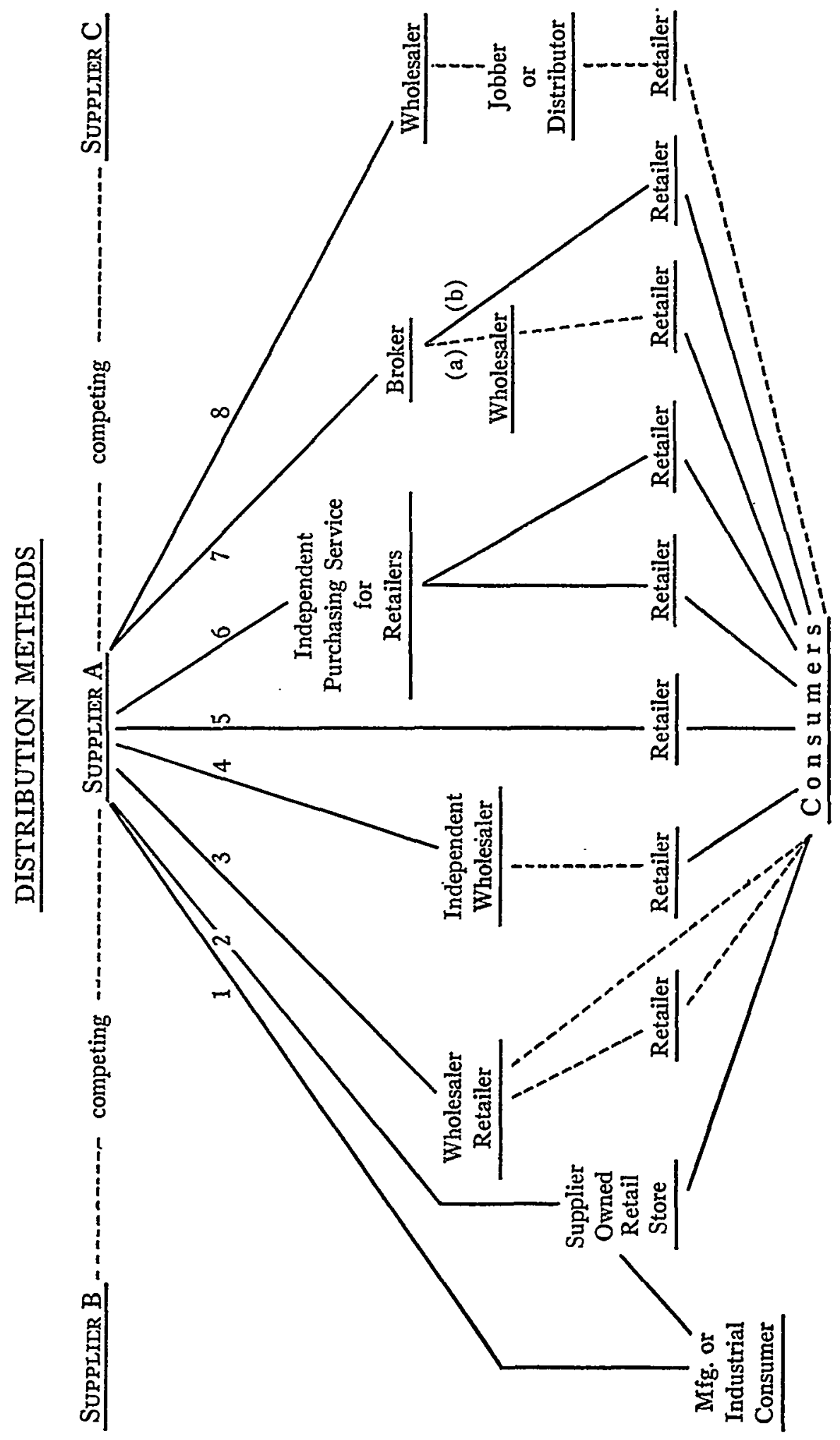


trade and functional discounts. The relationships represented by the dotted lines indicate that the supplier is insulated from control over these transactions. ${ }^{61}$ Solid lines indicate supplier determined price. The numbered lines indicate methods rather than individual transactions; thus, for instance, supplier $A$ using method 5 may enter into any number of transactions with any number of retailers. It is the use of more than one method of distribution that normally raises the problem of functional or trade discounts and price discrimination. ${ }^{62}$ This chart will aid in an analysis of those situations involving the use of multiple methods of distribution which the FTC has charged as violations of the Robinson-Patman Act.

\section{Use of Methods 1,2,4, and 5}

Champion Spark Plug Co. prices its plugs to a manufacturer user (Ford) for motor installations at 6 cents, to the same buyer for resale at 22 cents, and to distributors (wholesalers) at 26 cents. Champion is thus using methods 1 and 4 . The FTC alleges a violation of the Robinson-Patman Act. ${ }^{63}$ Distinctive packaging and tax considerations prevent original equipment plugs from being resold by Ford in its distributive capacity. Had the FTC charged Ford as a distributor with receiving a 4 cent differential over other distributors, the case would not present unique facts, but instead Ford's two prices are averaged and the resultant $161 / 2$ cent figure is contrasted with the 26 cent price to other distributors. ${ }^{64}$ The 6 cent price to Ford is not a trade discount, as defined herein. Ford is a consumer, not a distributor of the 6 cent plugs. Ford's bargaining power (niass purchases, steady requirements, threat of self production, etc.) determine the price. Part of the differential between 6 cents and 26 cents is functional in the sense that distributive costs to Champion are all but eliminated. ${ }^{65}$ The sale is to a powerful buyer in a noncompetitive segregated inarket at a price sufficient to cover marginal cost at present output. Who can be harmed? Other manufacturers of plugs, says the FTC. ${ }^{66}$

This is not a case of geographically selected price discrimination. ${ }^{67}$ Other plug manufacturers are free to bid for Ford's account. If they cannot

61 No resale price contract exists and no agency or quasi agency status of buyers is implied.

62 Sales at different prices to different customers all of whom are classified at one level of distribution can raise functional but not trade discount problems.

03 Champion Spark Plug Co., supra note 5.

6. A weighted average of $16 \mathrm{I} / 2$ cents resulted from more plugs sold Ford in its distributive capacity than sold for motor installations.

65 Despite Ford's use of the 6 cent plugs as a consumer, Champion's costs of distribution for those plugs undoubtedly are less than costs of distribution for plugs sold wholesalers. Though Ford as a consumer performs no distributive function, as a unique buyer it eliminates distribution costs.

66 See note 63 supra. The case is interestingly discussed by Hansen and Smith, The Champion Case: What is Competition?, 29 HARv. L. REv. No. 3, p. 89 (1951).

67 Where two family interconnected firms enjoyed a substantial inonopoly in the sale of chicory and lowered their prices in a special geographical area with the expressed intent to force out a small competitor whose sales were confined to that area, the FTC and reviewing court found a violation of $\S 2$ (a) which tended to create a monopoly in the discriminator's level of competition. E. B. Muller \& Co., 33 F.T.C. 24 (1941), affd, Muller v. FTC, 142 F.2d 511 (6th Cir. 1944). 
meet the 6 cent price quoted by Champion, their loss is not caused by Champion's multiple pricing, but instead by Champion's ability to cover marginal cost at 6 cents. ${ }^{68}$ If Champion's low prices to Ford for motor installation cannot hurt the resale trade, ${ }^{69}$ then the FTC's position would result only in raising Champion's price so competitors could bid for the Ford account. This is hardly a boon to competition. Champion's sales to Ford illustrate a fully vertically integrated seller making sales to a consumer who represents a uniquely segregated market, yet whose demand can be supplied by Champion's competitors if they can meet Champion's price. The Commission thus seeks to protect competitors at the expense of competition.

The use of method 2 coupled with a differential in prices between separately classified consumer customers resulted in a cease and desist order against U. S. Rubber and Tire Dealers' Corp. as early as $1939 .{ }^{70} \mathrm{~A}$ fully integrated tire manufacturer selling to consumers through wholly owned company retail stores segregated "commercial account" consumers from day to day purchasers. Lower prices were charged the "commercial account" buyers. No doubt exists that some of the differential was functional. That is, "commercial accounts" traditionally require less selling costs than day to day purchasers. No buyer competition was harmed. Consuming purchasers don't resell. Who was harmed? Again the FTC answers-competing sellers. No evidence was introduced to show other sellers could not compete for the same market. The Commission regarded as irrelevant any suggestion that U.S. Rubber was willing to take less profit on its sales to a segregated market buyer incapable of spoiling U. S. Rubber's remaining consumer market simply to induce such purchases. The cease and desist order allowed only differentials not greater than provable cost savings. ${ }^{71} \mathrm{~A}$ seller whose costs are lower than those of a competitor ${ }^{72}$ seemingly can't reduce his greater margin of profit by more than an amount equal to cost savings ${ }^{73}$ to extend his market to areas of varying buyer demand, even though all segments of such demand are classified consumers. U. S. Rubber's complete

68 The economic situation hardly lends itself to any long term sales by Champion below marginal costs. Though some suppliers have at times sold below marginal costs temporarily to drive out weaker competitors, a hasty return to ligher prices was necessary to survive. Cliampion's price policy is long term and there are large and powerful competitors, namely Autolite and A. C. Sparkplug Co.

69 The FTC does allege that Ford car owners are likely to replace tlieir plugs with the same brand as originally installed. In this manner it is charged that Champion stimulates replacement plug sales at ligh prices by selling original installation plugs below cost with resultant harm to Champion's competitors. Supra note 63.

70 U.S. Rubber Co., 28 F.T.C. 1489 (1939).

71 "It is further ordered, that respondents . . . cease and desist from discriminating in price ... by selling sucl products to some users and consumers thereof including so-called "commercial accounts," at prices different and lower than the prices charged other retail purchasers thereof, except to the extent that sucl differential or differentials sliall make only due allowance for differences in cost of manufacture, sale, or delivery, if any, resulting from differing methods or quantities in which sucl products are to sucl purchasers sold or delivered." Id. at 1505 .

T2 Whether this was so in the U.S. Rubber situation is unknown.

73 Varying his profit margin to fit the varying consumer demand of segregated market buyers is prollibited. 
integration of the distributive function conceivably lowered the costs of these functions so that its margin of profit greatly exceeded that of indidivual competing retailers of other brands. To limit its differential to "cominercial account" buyers to cost savings resulting from different methods of selling denies the coinpany the right to use its integration savings as a competitive tool and denies certain purchasers the benefit of lower prices.

The Commission enjoys some discretion in the issuance of complaints. ${ }^{74}$ The decision to prosecute these two cases, as representative of the type of injury to competition at the discriminator's level of distribution which will invalidate price differentials, seems unfortunate.

In American Oil Co. ${ }^{75}$ a fuzzy authority to support any conclusion, ${ }^{76}$ it appears that the FTC prohibited American Oil from selling via method 1 to a large scale consumer at lower prices than to retailers by method 5 . General Fimance owned a fleet of taxicabs. It also retailed gasoline in competition with other retailers. American Oil's price to General Finance in their final sales contract equaled the price offered other competing retailers, ${ }^{7 \tau}$ but American rebated 15/8 cents per gallon to General Finance for that portion of gasoline consumed by General Finance's taxis. ${ }^{78}$ The prohibition of this rebate is a possible interpretation of the order. If a correct interpretation, we have another instance where a differential could not possibly hurt buyer competition, ${ }^{\text {T9 }}$ nor could it lessen competition in the resale of gas between "custoniers of either of them". ${ }^{80}$ Could the practice hurt American's competitors? Only if we can conclude they lost business to American Oil because they were unwilling to sell to General Finance for use in taxicabs at conipetitive prices. This would seem to be nothing but competition's attrition of sellers who refuse to ineet it.

The FTC's order in the Moss case ${ }^{81}$ reached the Courts. ${ }^{82}$ Here a inanu-

74 Before issuing complaints, the FTC by the terms of the statute vesting them with authority to enforce $\$ 2$ of the Clayton Act as amended by the Robinson-Patman Act, is required to have "reason to believe" that the Act is being violated or has been violated. 38 STAT. 730 (1914), 15 U.S.C. $\$ \$ 5,12-27$ (1946). This would seem to include the element of injury to competition which patently appears missing in the two cases discussed.

7529 F.T.C. 857 (1939).

76 The FTC order written in the prohibitory terms of the Act with reference back to the findings in the case makes it difficult to conclude just what practices were being prohibited. Id. at 867 . See inconsistent conclusions reached by two other writers. Bartenstein, Functional Discounts under the Robinson-Patman Act, 4 WASH. \& LEE L. REv. 121 (1947); Schniderman, supra note 14 at 596 .

77 Previous contracts had provided for a price differential between the gas sold General Finance for taxi consumption and that sold General Finance in the capacity as a retail distributor.

78 Supra note 75 at 864 .

70 General Finance in its consuner capacity as an owner of taxicabs using gas is not in competition with other retailers charged higher prices, for as a consumer it does not resell gas.

80 Taxicab companies compete in "service," not gasoline sales. However, varying prices in cost factors involved in furnishing such "service" admittedly may advantage the lower price buyer.

81 Samuel H. Moss, Inc., 36 F.T.C. 640, 650 (1943).

82 Samuel H. Moss, Inc. v. F.T.C., 148 F.2d 378 (2d Cir. 1945), cert. denied, 326 U.S. 734 (1945), clarified, 155 F.2d 1016 (2d Cir. 1946). 
facturer of rubber stamps selling direct to consumers by method 1 was charged by the FTC with selling to some of its customers at lower prices than to others. The result of the court's per curiam opinion, which upheld the FTC's cease and desist order forbidding continuance of the differential pricing, was to outlaw presumptively all price differentials and place the burden on the seller to prove the differentials did not tend to lessen or prevent competition between himself and his competitors. ${ }^{83}$ This seems an unwarranted interpretation of the Act. ${ }^{84}$ The wording of the Act makes discriminations in price illegal only under specific circumstances. ${ }^{85}$ The proof of all the circumstances seems a necessary part of the FTC's burden, unless price differentials per se are to be considered unlawful price discriminations. Since evidence tending to prove no injury to competition resulted was excluded as irrelevant, the per se unlawfulness becomes the more apparent. Aside from this dubious interpretation, the case presents another situation in which if any harm to competition resulted, it must have been to competing sellers. Evidence offered by Moss that was rejected by the trial examiner and held irrelevant by the reviewing court indicated the differentials were made only to retain or regain customers who would otherwise buy elsewhere. ${ }^{86}$ This was not a monopoly crushing competition by selective price cutting, ${ }^{87}$ but a competitive business struggling to survive. It is doubtful whether the FTC's order could have been sustained had not the court relieved the Commission of the burden of proving essential elements of illegal price discrimination.

\section{Dual Function Buyers and Methods 3 and 5}

Any attempt to systematize buyers into rigid single function classifications is unrealistic. ${ }^{88}$ Determining a inultiple function buyer's classification by his last function in the distributive system ignores economics. When two or inore functions in the distributive system are performed by a single firm, a discount sufficient to cover the costs and profits for both functions should

83 The court stated "[this] put upon the petitioner [Moss] the burden of justifying the discrimination .... The petitioner did not prove affirmatively that the discrinination did not lessen competition or tend to prevent it ...." Id. at 379. The court was using the word "discrimination" as synonomous with "differential."

84 See Austern, supra note 53 at 72 , where he writes, "On any grammatical reading of the text of the Act, this constituted an unwarranted judicial rewriting of both Sections [\$§ 2(a) and $2(\mathrm{~b})]$."

85 Section 2(b) of the Act reads in part: "[It] shall be unlawful for any person ... to discriminate in price ... [1] where either or any of the purchasers . . . are in counmerce, [2] where such commodities are sold for use, consumption, or resale within the United States ..., and [3] where the effect of such discrimination may be substantially to lessen competition or tend to create a monopoly in any line of commerce or to injure, destroy or prevent competition with any person who either grants or knowingly receives the benefit of such discrintination or with customers of either of them." (Emphasis added.)

86 "In the light of what we have already said [that the burden is on the alleged discriminator to prove the differential in price did not tend to injure competition] this testimony was not relevant to the issue." Samuel H. Moss, Inc. v. FTC, supra note 82 at 380.

87 See note 67 supra.

88 Manufacturers perform both wholesale and retail functions. McNair, Marketing Functions and Costs and the Robinson-Patman Act, 4 LAw \& Contemp. Prob. 334, 339 (1937). 
be allowed. Economies resulting from joint performance of the two functions should not be blocked at any level of distribution by arbitrary classification. The fallacy of allowing a wholesaler-retailer only the retail discount on that portion of the product he retails lies in the belief that he does not perform the wholesale function for that portion. Though wholesale function costs of wholesaling to oneself may be less than when wholesaling to independent purchasers, nevertheless they are not non-existent. ${ }^{89}$

In Shervein Williams $\mathrm{Co}^{90}$ a paint manufacturer and its two subsidiaries, Lowe Bros. and Lucas, sold direct to retailers and to wholesalerretailers, the latter purchasers selling both to other retailers and to consumers. Wholesaler-retailer purchasers from the subsidiaries failed to keep accurate records revealing what portion of their purchases was resold to retailers as distinguished from that sold to consumers. Only estimates were submitted by the wholesaler-retailer to its suppliers, and a wholesale discount, not granted direct retail buyers, was allowed on that estimated percentage sold to retailers.

The FTC, after investigation and hearing, issued a cease and desist order. ${ }^{91}$ The Commission's theory was that retailers buying directly from Lowe Bros. and Lucas were in competition with the dual function purchasers for the consumer market, and since the dual function purchaser received wholesale discounts on some of his purchases which he resold direct to consumers, competing retailers were harmed ${ }^{92}$ Except for one instance, ${ }^{93}$ the dual function purchasers' price on sales to retailers was equal to or greater than the suppliers' direct sales price to retailers. The Commission's order prevents dual function buyers (buyers integrating retail and wholesale functions) from receiving a wholesale price on any purchases sold direct to consumers. ${ }^{94}$ This philosophy stems from the Mennen ${ }^{95}$ decision which, in circumstances somewhat comparable ${ }^{96}$ implied that a buyer's classification is determined by his last distributive function. Such an arbitrary classification perpetuates rigid distributive systems. Requiring a wholesaler-retailer, who performs wholesale functions (warehousing, quantity purchases, as-

89 See notes 8 and 9 supra.

8036 F.T.C. 25 (1943).

91 Id. at 71 .

92 Paragraph 22 of the Commission's findings, id. at 70.

03 One dual function purchaser, Waite Hardware Co., undercut his supplier's price to retailers. Paragrapls $17 \mathrm{C}$ of the Commission's complaint, id. at 41 . This problem of functional discounts involving different prices to direct and indirect purchasers, later raised in the Standard Oil case, was at this time dismissed by the FTC without prejudice. Id. at 75 .

94 The portion of the order discussed reads: cease and desist "From discriminating in price between dealer and dealer-distributor custoiners through the practice followed under present and prior discount plans of granting and allowing to some of its dealer-distributors customers' discounts (in addition to the regular per order or volume discounts from dealer list prices in effect at the time and granted and allowed to all of its customers) on such portion of the purchases of said dealer-distributor customers." Paragraphs 2 and 4 of the FTC's cease and desist order, $i d$. at 73,74 .

05 Mennen Co. v. F.T.C., supra note 18.

08 The purchasers in Mennen were retailers but had banded together to make mass purchasers on a scale equal or greater than those by wliolesalers. 
sumption of market risks, advertising, etc.) on all purchases and retail functions (store outlet, service, credit carrying, deliveries to customers, clerk hire, etc.) on some purchases to pay retail prices on that portion of the product sold direct to consumers is itself economic price discrimination. ${ }^{07}$ The FTC clearly does not intend to prevent price discrimination produced by a seller failing to allow full cost savings for functions performed by the buyer by not allowing such buyer a lower price than a buyer not performing the functions. ${ }^{83}$ However, prohibiting a seller from granting lower prices to function performing buyers than those granted to non-performing buyers prevents consumers from receiving the economic savings that can be affected by upward intergration in the distributive system. To argue that the dual function purchaser in his capacity as a retailer necessarily competes unfairly with direct buying retailers because of the different cost prices paid the supplier for the product is unsound economics. ${ }^{99}$ Before a total cost price comparable to that paid by the single function retailer can be reached, there must be added to the wholesale price which the dual function purchaser pays his costs for performing the wholesaling function. Any differential between such total cost prices favoring the dual function buyer may be caused by his self-performance of the wholesale function at lower cost than the same function is performed for the single function buyer by the supplier, rather than by any discrimination by the supplier between purchasers. Little incentive remains for retailers to integrate upward and receive wholesale cost prices in hope of reducing the cost of the wholesale function. Competition in the wholesale function is reserved to wholesalers. It seems axiomatic that competition can best be stimulated by removing barriers to entry rather than building them.

The facts of Standard Oil Co. ${ }^{100}$ highlight several functional discount problems. One such problem relates to sales to dual function distributors. Standard sold to four accounts which it classified as jobbers. It also sold direct to retailers. A price differential of $1 \mathrm{I} / 2$ cents existed between classifications. Three of the four jobber accounts sold directly to consumers as well as to retailers. ${ }^{101}$ The jobbers provided bulk storage and made their own

97 Since the product-service exchanged in sales to buyers not performing wholesale functions is larger than the product-service exchanged in sales to buyers performing wholesalc functions, an equal price to both is economic price discrimination. See note 7 stlpra.

08 Bird and Son, Inc., 25 F.T.C. 548 (1937) (an equal price to wholesalers and to a mass buying retailer held no violation of the Act). See full discussion of the case in the text infra at note 123 .

${ }^{09}$ Speaking of integration, one writer says, "As the firm integrates, it performs additional functions and incurs additional costs. Only by a careful examination of those costs can we tell whether the business is discriminating on the buying or selling sides or whether it is itself experiencing discrimination .... A mere differential or lack of a differential in price means nothing whatever unless and until informaton is available on a corresponding cost differential." Adelman, supra note 8 at 40 .

10041 F.T.C. 263 (1945), modified, 43 F.T.C. 56 (1946), modified and aff'd., Standard Oil v. FTC, supra note 11 .

101 One of the four accounts classified as jobbers was Ned's Auto Supply Co. It sold direct to consumers all the gasoline it purchased from Standard. 
deliveries to retailers. The modified order of the FTC ${ }^{102}$ following the pattern set in Sherwin Williams, required the price of gasoline sold to jobbers that was resold direct to consumers to be equal to the price of gasoline sold to single function competing retailers. With respect to this part of the order, a circuit court affirmed. ${ }^{103}$ On certiorari the order was reversed on other grounds..$^{104}$

Both the jobbers in Standard and the dual function distributors in Sherwin Williams possessed bargaining power derived from the character of their purchasing which enabled them to obtain lower prices from suppliers than were accorded single function retailers. ${ }^{105}$ The price differentials were functional. Only the Standard order allowed for differentials equal to provable differences in costs of serving retailers and wholesaler-retailers. ${ }^{106} \mathrm{But}$, the fact that all ${ }^{107}$ differentials justified by cost savings are specifically allowed by the Act ${ }^{108}$ emphasizes the order as a prohibition of this type of functional discount per se.

The Commission's latest order in Standard ${ }^{109}$ makes no change with respect to this problem. Though couched in terms of prohibiting price differentials between retailers, the Commission explains that the "retailer" classification refers to that portion of the business of any purchaser which consists of the retail sale of gasoline to the public. ${ }^{110}$

102 Paragraph 5 of the FTC's cease and desist order, Standard Oil Co., 43 F.T.C. at 58, supra note 100 .

103 Standard Oil v. FTC, I73 F.2d 210, supra note 11.

104 Standard Oil v. FTC, 340 U.S. 231, supra note 11 . The Court, by a five to four decision, held $\S 2$ (b) a substantive defense to a charge of price discrimination.

105 They purchased in large quantities, had established credit ratings, and performed the normal wholesale functions which save suppliers distributive costs.

106 Paragraph (b) of the FTC's cease and desist order, Standard Oil Co., 43 F.T.C. at 57, supra note 100 .

107 There are two major exceptions. (1) The Commission has the authority to set upper bmits on the quantities which can be bought at specified discounts within supplier's pricing systems. Section 2 (a) provides in part, "Provided, however, that the Federal Trade Commission may, after due investigation and hearing to all interested parties, fix and establish quantity limits, and revise the same as it finds necessary, as to particular commodities, where it finds that available purchasers in greater quantities are so few as to render differentials on account thereof unjustly discriminatory or promotive of monopoly in any line of commerce; and the foregoing shall then not be construed to permit differentials based on differences in quantities greater than those so fixed and established." This proviso implies that any cost savings resulting from sales in quantities larger than those fixed by the FTC cannot be reflected in lower prices. The Commission has recently for the first time exercised its authority under this proviso and set 20,000 lbs. as the maximum limit for quantity price differentials on tires and tubes. Quantity Limit Rule No. 203-1, CCH TrAde REg. ReP. (9th ed.) II 11,011 (1952). Suit has been filed by the tire and tube manufacturers against the FTC in the U.S. District Court for the District of Columbia to have the rule declared void. (2) By interpretation of $\S 2$ (c), any attempt to justify a differential in price based on a savings in cost through elimination of brokerage is invalid.

108 Section 2 (a) provides, "That nothing herein contained shall prevent differentials wlich make only due allowance for differences in the cost of inanufacture, sale, or delivery resulting from the differing methods or quantities in which such commodities are to such purchasers sold or delivered."

109 CCH Trade Reg. Rep. (9th ed.) $\llbracket 14,925.40$ (1952).

110 The order requires Standard to refrain from discriminating in the price of gasoline of like grade and quality: "By selling such gasoline to any retailer thereof at a lower price than 
One economic result of the Standard and Sherwin Williams orders is the creation of a barrier to downward integration by wholesalers and upward integration by retailers which can be avoided only by proving that the lower prices granted the integrated purchasers are justified under the cost justification proviso of the Act. The loss is to consumers, for the integrations present in Standard and Sherwin Williams resulted in lower prices to the public. $^{111}$

Methods 4 and 5 and "to injure, destroy, or prevent competition . . . with customers of either of them"

When suppliers sell both to wholesalers and direct to retailers in the same area, they may find themselves competing with their wholesale customers for the trade of their retail customers. When suppliers choose to meet this competition, their obvious method is to make the differential in price between wholesale and retail customers so small that wholesalers do not have enough margin to be able to undercut their supplier's price to direct buying retailers. Reducing the differential has its obvious limits. Set too low, wholesalers will refuse to buy, or the supplier's costs of performing the wholesale function to direct buying retailers will not be covered by the higher price charged for serving them. If wholesalers can perform the wholesale function more efficiently than their suppliers, the cost savings enjoyed by suppliers on sales to wholesalers as compared with sales to retailers will be larger than the wholesaler performance costs. But since suppliers cannot be expected to perform the wholesale function in their sales to retailers at cost (in the accounting sense) any more than wholesalers could be expected to furnish a service at cost, a margin of profit must be earned to justify such a method of distribution. Though realistically the profit for performing the wholesale function on sales by suppliers to direct buying retailers is merged with producer profits, as are the costs of production and wholesaling, separation of costs and profits of the two functions becomes necessary in analyzing the justification for the wholesale price differential. ${ }^{112}$

The Robinson-Patman Act permits only accounting cost savings in measuring the differential allowable. Profits not earned by the supplier on functions he does not perform should be included as a permissible item in measuring allowable price differentials.

The facts of the Standard case raised the problems just discussed. ${ }^{113}$ One of the jobbers (wholesalers) to which Standard sold undercut Stand-

\footnotetext{
to any other retailer who in fact competes with the favored purchasers in the resale of such gasoline to the public." CCH TRADE REG. REP. (9th ed) $114,925.40$ (1952).

111 Certain "commercial account" consumers in Sherwin Williams and the general public in Standard paid lower prices when purchasing from the dual function distributors. See FTC findings in Sherwin Williams Co., supra note 90 at 49, and Standard Oil Co., supra note 100 at 267 .

112 See Adelman, supra note 8 at 32 .

113 It was earlier raised by the facts in Sherwin Williams, but not settled at that time. See supra note 88.
} 
ard's price to retailers. ${ }^{114}$ Thus, a wholesaler under method 4 sold to retailers at a lower price than his supplier charged retailers under method 5. The FTC's modified order prohibited Standard from granting any trade discount not justified by cost savings to wholesalers who undercut Standard's direct price to retailers. ${ }^{115}$ The circuit court affirmed with the modification that the undercutting must be within the knowledge of Standard or under circumstances such that knowledge would be reasonably imputed. ${ }^{116}$ On certiorari the order was reversed on other grounds, ${ }^{117}$ with the merits of this problem left undecided. As indicated earlier, ${ }^{118}$ the FTC has further modified its order, and the latest version omits reference to this problem. Seemingly, the Commission has decided not to condemn a trade discount under these circumstances.

Inconsistency between the statements of the FTC's Chairman and the Commission's order would have resulted had the Commission decided to retain this portion of the order. Chairman Mead, in a speech in Chicago before the annual meeting of the Motor and Equipment Wholesalers Ass'n said, "I can assure you that the Commission has never issued an order in a price discrimination case under the Clayton Act, as amended by the Robinson-Patman Act, forbidding a manufacturer to grant a functional discount as such." "Even allowing that the Chairman's use of "functional discount" was in the sense of a trade discount, ${ }^{120}$ the Commission's original modified order did prohibit "functional discounts as such".121

The Commission's theory, sustaining the prohibition of trade discounts to wholesalers undercutting their supplier's direct price to retailers, was that retailers purchasing directly from Standard were paying higher prices

114 Citrin-Kolb Oil Co. sold to some retailers at two cents per gallon and to other retailers at one cent per gallon cheaper than such retailers could buy from Standard direct. Supra note 11 at 212 .

115 Standard was ordered to cease and desist price discrimination "by selling such gasoline to any jobber or wholesaler at a price lower than the price which the respondent charges its retailer-customers who in fact compete in the sale and distribution of such gasoline with the retailer-customers of such jobbers or wholesalers, where such jobber or wholesaler resells such gasoline to any of its said retailer customers at less than respondent's posted tank wagon price or directly or indirectly grants to any such retailer-customer any discounts, rebates, allowances, services, or facilities having the net effect of a reduction in price to the retailer." Paragraph 6 of the FTC's modified cease and desist order, Standard Oil Co., 43 F.T.C. at 58, supra note 100. Proviso (c) of the order read, "That none of the prohibitions of the order shall be taken as inhibiting a lower price to jobbers than to retailers where respondent thereby makes only due allowance for its differences in cost of inanufacture, sale, or dehvery resulting from the differing methods or quantities in which such gasoline is to such purchasers sold or delivered."

110 Standard Oil Co. v. FTC, supra note 11 at 217.

117 The Court reached the result that $\$ 2(b)$ of the Act was a substantive defense and remanded the case to the circuit court with instructions to remand it to the FTC for findings with respect to whether Standard had brought itself within the defense. Standard Oil Co. v. FTC, 340 U.S. 231, supra note 11.

118 See note 110 supra.

110 CCH TRade Reg. Rep., Report 230, p. 5 (Dec. 20, 1951).

$120 \mathrm{~A}$ discount that is based entirely on the status of the purchaser classified by his selling characteristics.

121 Standard Oil Co., 43 F.T.C. at 58, supra note 100. The order was directed at a discount granted a purchaser classified a wholesaler by the Commission's own method of classification. 
than retailers purchasing from the undercutting wholesaler. Since the Act prevents injury to competition "with customers of either of them", the Act was violated when a customer of the wholesaler received a competitive advantage over a customer of the wholesaler's supplier.

With the situation reversed, where the price to a retailer buying direct is lower than the price to a retailer purchasing through wholesalers, there would seem to be no violation. ${ }^{122}$ The fact that retail buyers purchasing direct would then have the competitive advantage seems irrelevant to the Commission. The facts of the Bird case raise this very issue. ${ }^{123}$

Bird and Son, Inc., a manufacturer of linoleum rugs, decided, after passage of the Robinson-Patman Act, to sell at one price to all buyers. This action, in effect, reduced its wholesaler differential to zero. It did, however, limit its customers to single function wholesalers and one large retail mail order firm. The fact that retailers purchasing from Bird's wholesale customers paid higher prices than the competing mail order firm did not concern the Commission. Bird had not charged its customers different prices.

Thus, despite the oft quoted Utterbach definition of price discrimination, which emphasized that price discrimination was more than a price differential, ${ }^{124}$ it appears from this interpretation of the Act that there must at least be a differential. Presumably, Bird's selection of customers was "not in restraint of trade". ${ }^{125}$ The Commission dismissed the complaint, bolstering its opinion with words to the effect that the Act was not meant to force sellers to grant lower prices to wholesalers than to retailers. ${ }^{126}$

Assume Bird later decides to sell directly to certain of those retailers who formerly purchased from Bird's wholesale customers and assume fur-

122 Bird and Son, Inc., supra note 98. Austin, Price Discrimination and ReLated ProbIEMS UNDER THE RoBINSON-PATMAN ACT 47 (1950) where he describes such facts an an example of a supplier "simply making use of his lawful competitive advantage." Cf. A. J. Goodman \& Son v. United Lacquer Mfg. Corp., 81 F. Supp. 890 (D. Mass. 1949) (where the price to the consumer necessarily was lower than the intermediary distributor could have quoted). But cf., Morton Salt Co. v. FTC, 334 U.S. 37 (1948) (where a lower price to retailers than that granted wholesalers was prohibited).

123 Bird and Son, Inc., supra note 98.

124 His definition, expressed in debate on the floor of the House, was: "In its meaning as simple English, a discrimination is more than a mere difference. Underlying the meaning of the word is the idea that some relationship exists between the parties to the discrimination which entitles them to equal treatment, whereby the difference granted to one casts some burden or disadvantage upon the other. If the two are competing in the resale of the goods concerned, that relationship exists. Where, also, the price to one is so low as to involve a sacrifice of some part of the seller's necessary costs and profit as applied to that business, it leaves that deficit inevitably to be made up in higher prices to his other customers; and there, too, a relationship may exist upon which to base the charge of discrimination." 80 CoNG. REC. 9416 (1936).

I25 "There is no suggestion that the selection of customers here involved was the result of any combination in restraint of trade." Bird and Son, Inc, sttpra note 98 at 553.

108 "Not until there is a discrimination in price among those chosen does Section 2 (a) of the Act have any application." Ibid. The FTC was undoubtedly using the word "discrimination" as synonomous with "differential." In an earlier paragraph of the opinion the FTC says: "By the end of October 1936, no goods were being sold direct to retailers [by Bird] while jobbers and mail order houses were being sold at the same net prices." Id. at 552. In view of the Commission's attitude toward classification of all purchasers selling to consumers as retailers, the statement is irreconcilable. 
ther that Bird charged such new customers the same price charged them by such wholesalers. Bird suddenly becomes a violater of the Act for discriminating between retailers. No economic change resulted. Bird, in order to avoid violation, would have to justify the price differential which would then exist between these new customers and the mail order firms as a cost saving resulting from serving the mail order firms. When economic effects are indistinguishable, yet the law distinguishes them, small wonder that the economic wisdom of the Act is challenged.

Are purchasers through wholesalers purchasers from the original supplier? Bird said no, Kraft-Phenix Cheese Corp ${ }^{127}$ said maybe. When a supplier solicits sales from indirect customers buying through the supplier's wholesaler, or when the supplier controls his wholesaler's price to retailers, ${ }^{128}$ then such indirect purchasers are purchasers from the supplier and must not be charged a different price than direct purchasers from the supplier. This is not a serious inroad on the Bird doctrine, since a one-price policy hardly leaves the wholesaler in any position to compete with his supplier for retail customers, and suppliers are under no compulsion to solicit customers for their wholesalers.

The Bird opinion may leave the door wide open to the very price discriminations the Act seeks to prevent. Sellers, well knowing the difficulty of proving cost justifications under the cost proviso of the Act, ${ }^{129}$ could in all sincerity and good faith decide to sell only to those retail customers they feel justified in serving at the same price they charge wholesalers. These would probably be large chains and other mass purchasers. Rather than sell to all retailers on a sliding scale of prices measured by quantities, requiring cost justification for each differential, the seller could force small quantity purchasers entirely off the scale by refusal to sell to them at all. ${ }^{130}$

12725 F.T.C. 537 (1937).

128 In supporting its argument that Kraft was operating in interstate commerce, the FTC reached the conclusion that customers buying from wholesalers, when such wholesalers' resale prices were fixed by their suppher [Kraft] or when the customers' purchases were solicited by $\mathrm{Kraft}$, were customers of Kraft. Thus the price to both direct and indirect customers must be equal or otherwise cost justified to avoid a charge of discrimination. Id. at 542 . But cf., Burroughs Welcome Co. v. Johnson Wholesale Perfume Co., 128 Conn. 596, 24 A.2d 841 (1942) (held no violation of the Act where a supplier refused to sell to a purchaser and such purchaser had to buy from the supplier's wholesaler whose price was fixed by the supplier under a fair trade contract and which price was higher than the supplier's direct price to other retailers).

120 For the difficulties encountered by some companies attempting cost defense before the Commission, see e.g., Minneapolis-Honeywell Regulator Co., 44 F.T.C. 351 (1948); Standard Oil Co., supra note 100; see also results of similar attempts before the courts in private actions. Bruce's Juices v. American Can Co., 87 F. Supp. 985 (S.D. Fla. 1949), aff'd, 187 F.2d 919 (5th Cir. 1951) ; Russellville Canning Co.v. American Co., 87 F. Supp. 484 (W. D. Ark. 1949), rev'd., 191 F.2d 38 (8th Cir. 1951). One writer's conclusion is- "Under current interpretations a cost defense, as a practical matter, is impossible." Rowe, supra note 2 at 963.

130 Refusal to sell has been held not violative of $\S 2(a)$. Shaw's Inc. v. IVilson Jones Co., 105 F.2d 331 (3d Cir. 1939); Chicago Seating Co. v. S. Karpen \& Bros., 177 F.2d 863 (7th Cir. 1949). It has been argued that all purchasers must be accorded the right to purchase directly from the supplier by classifying the "right to purchase directly" "a 'service' or 'facility' which under Section 2(e) of the Act, must be accorded on proportionally equal terms to all purchasers." Hazlett, Price Discriminations and Their Justifications under the Robinson-Patman Act of 1936, 46 MrCE. L. REv. 450, 462 (1948). Little weight should be given this argument when 
It can be argued that the wording of the Act, requiring a discrimination in price before a violation occurs, precluded the FTC from any other result in Bird. ${ }^{131}$ But the inconsistent conclusion reached by the Commission in the basing point cases leaves one bewildered as to just what price discrimination means to the FTC. ${ }^{132}$ Though the waters are concededly muddied by issues of collusion, ${ }^{133}$ the FTC argues in the basing point controversies that savings in costs of transportation enjoyed by the seller in sales to different customers must be reflected as price differentials. ${ }^{134}$ Similarly, it would seem that cost savings resulting from sales to wholesalers, as contrasted to retailers, should be reflected in lower prices to wholesalers.

Regardless of the merits of opposing theories involved in the basing point controversy, the Commission's theory of price discrimination therein used is closer to economic reality than its theory in the Bird case. Paradoxically, however, the ruling of the Bird case may be the last possible way for mass purchasers to exert their buying power to receive lower prices than buyers not possessed of those advantages. Since the Commission persists in classifying retailer sellers as retailers, despite the character of their purchasing, a one-price policy effected by selling only to mass purchasing retailers and wholesalers at equal prices would allow the advantages of partial integration without the necessity for any proof of cost justification.

it is realized one is not a "purchaser" within 2(e) until the supplier sells to him. The same writer suggests "it may be that the Act requires a seller to accept direct orders from all would-be direct purchasers when the result otherwise would be price incquality among such purchasers." Id. at 463 . Both Morton Salt Co. v. FTC, supra note 122 (where the order precluded sales to retailers at lower prices than to wholesalers but would have no effect on equal prices to both), and Bird \& Son, Inc., supra note 98 (where equal prices to wholesalers and mass purchasing retailers was approved), seem to refute this argument. See also Burroughs Welcome Co., stupra note 128. But cf. United States v. Klearflax Linen Looms, 63 F. Supp. 32 (D. Minn. 1945) ( $\$ 2$ of the Sherman Act held violated where defendant refused sales to a customer at his normal discount because the customer was undercutting defendant in bids for government orders).

$131 \mathrm{By}$ arguing that a discrimination in price is the equivalent of a differential in price, no violation apparently can result from equal prices to all customers sclected by the supplier.

139 Equal delivered prices to buyers which result in varying "mill net" return to the seller can nevertheless be price discrimination. The Cement Institute, 37 F.T.C. 87 (1943), set aside, 157 F.2d 533 (7th Cir. 1946), rev'd. and remanded, 333 U.S. 683 (1948) ; Corn Products Refining Co., 34 F.T.C. 850 (1943), modified and aff'd., 144 F.2d 211 (7th Cir. 1944), aff'd., 324 U.S. 726 (1945); A. E. Staley Mfg. Co., 34 F.T.C. 1362 (1942), set aside, 144 F.2d 221 (7th Cir. 1944), rev'd. and remanded, 324 U.S. 746 (1945).

133 Price "systems" involving similar use by other manufacturers rather than price differentials were the features of all three cases that the Supreme Court found a violation of the Act. "We hold that the Commission properly concluded that respondents' pricing system results in price discriminations." FTC v. Cement Institute, 333 U.S. at 725, supra note 132; "We conclude that the discrimination involved in the petitioners' pricing system are within the prohibitions of the Act," Corn Products Refining Co. v. FTC, 324 U.S. at 737, supra note 132; "Respondents have never attempted to establish their own non-discriminatory price system .... . But it does not follow that respondents may never absorb freight when their factory price plus actual freight is higher than their competitors' price," FTC v. A. E. Staley Mfg. Co., 324 U.S. at 754, 767, supra note 132 . For excellent bibliography covering the basing point problem as related to the Robinson-Patman Act see Oppenneng, UnfarR Trade Practice 1116 (1950).

134 The same argument is being offered by the FTC in the present National Lead Case, FTC Docket No. 5253 (pending) (a uniform price to customers within zones is charged as discriminatory since freight costs vary and the seller's "net" differs depending on the location of the buyer). 
The ability of a supplier to "make use of his lawful competitive advantage" 135 by underselling his wholesaler in direct sales to retailers seems to have an arbitrary limit. In Morton Salt Co. v. FTC, ${ }^{136}$ the Commission's order prohibiting a supplier from making sales to a retailer at lower prices than to wholesalers was upheld. The character of purchases by some large retailers gives them greater bargaining power than many small wholesalers possess. Refusal to allow them lower prices than wholesalers denies functional discounts.

Summarizing the effect of the Act on distributive methods 4 and 5, we arrive at these anomalous results:

(1) Suppliers can charge both wholesalers and retailers equal prices despite the resultant price differential between direct buying retailers and those purchasing through wholesalers. ${ }^{137}$

(2) Under the original modified order in Standard, not presently in force, suppliers could not charge lower prices to wholesalers than to retailers when such wholesalers undercut the supplier's price to direct buying retailers. ${ }^{138}$

(3) Suppliers cannot charge lower prices to retailers than to wholesalers whose customers compete with such retailers. ${ }^{139}$

\section{Section 2(c) and Methods 6 and 7}

Without doubt, Section 2(c), ${ }^{140}$ as interpreted by the FTC with the complete support of reviewing courts, is the worst example within the Act of special interest legislation. The avowed intent of those who supported the section was to prohibit secret dummy-brokerage allowances. ${ }^{141}$ The result has far exceeded their intentions.

Since most writers on functional discounts have treated such discounts as synonomous with trade discounts, Section 2 (c) rightfully has no place in their discussions. ${ }^{142}$ What could be a more likely situation in which to allow a buyer a functional discount than when the buyer performs the brokerage function, which otherwise must be contracted for at the seller's ex-

135 See note 122 supra.

130 Supra note 122.

137 Bird \& Son, Inc., supra note 98.

139 Paragraph 6 of the cease and desist order, 43 F.T.C. at 58, supra note 100. The failure of the FTC to make clear in its most recent order in Standard whether it still considers that such a situation makes the suppher a violator of $\S 2(a)$ is unfortunate. See note 125 supra.

339 FTC v. Morton Salt Co., supra note 58.

140 "That it shall be unlawful for any person engaged in commerce, in the course of such commerce, to pay or grant, or to receive or accept anything of value as a commission, brokerage, or other compensation, or any allowance or discount in heu thereof, except for services rendered in connection with the sale or purchase of goods, wares, or merchandise, either to the other party to such transaction or to an agent, representative, or other intermediary therein where such intermediary is acting in fact for or in behalf, or is subject to the direct or indirect control, of any party to such transaction other than the person by whom such compensation is so granted or paid. 49 Srax. 1526 (1936), 15 U.S.C. \$ 13 (1946).

141 See note 49 supra.

142 Brokerage allowances or allowances in lieu of brokerage do not fit within trade discount definitions, since they are allowed only to certain buyers competing with others to which they are not allowed. 
pense! It is argued in support of the section that buyers cannot perform the brokerage function on purchases for themselves. This argument parallels the similar one that dual function buyers do not perform wholesale functions on purchases they retail direct to consumers. Both are subject to the same fallacy. ${ }^{143}$

As will be seen in a discussion of the cases, "services rendered" has been read out of the Act, ${ }^{144}$ which also fails to contain any requirement of a price discrimination. ${ }^{145}$ Further interpretation read out the necessity for the fundamental element of injury to competition. ${ }^{146}$ Finally, proof that a buyer purchasing without the services of a broker saves the seller an amount equal to, greater, or less than the brokerage cost, thus deserving a price lower than that charged those buying through brokers, is considered irrelevant. ${ }^{145}$

Section 2(c) has been construed more often by the Commission and courts than any other section of the Act. ${ }^{148}$ Though one may doubt the efficacy of the provision, there is little doubt left as to its meaning. By interpretation, its prohibitions have been broadened to such a degree it is possible to say unequivocally that there is no such thing as a lawful functional discount granted for the performance of the brokerage function.

An independent broker is normally neither buyer nor seller. $\mathrm{He}$ is a go-

143 Failure of an economic entity, separate from buyer and seller, to exist as a mechanism for the performance of functions involved in the transfer of goods does not prove that those functions are not performed.

144 Biddle Purchasing Co. v. FTC, 96 F.2d 687 (2d Cir. 1938), cert. denied, 305 U.S. 634 (1938) (an independent buying service cannot render "selling" services); Oliver Bros., Inc. v. FTC, 102 F.2d 763 (4th Cir. 1939) (operative legal facts identical with the Biddle case) ; Great Atlantic and Pacific Tea Co. v. FTC, 106 F.2d 667 (3d Cir. 1939), cert. denied, 308 U.S. 625 (1940) (buyers performing brokerage functions are not rendering services to sellers).

145 Biddle Purchasing Co. v. FTC, supra note 144. The decision of the court recognized that many of the buyers under the plan were actually paying more for the commodities purchased than were buyers purchasing through ordinary brokers. Swan, J. dissented from this portion of the court's opinion. The dissent argues that $\S 2(\mathrm{c})$ should be subject to at least that portion of $\$ 2$ (a) which requires a "price discrimination." Logically, if subject to any portion of $\S 2(a)$, then $2(c)$ should be subject to all parts including the cost justification proviso.

146 Ohver Bros., Inc. v. FTC, supra note 144. The court, after discussing the contention by Oliver Bros. that $\$ 2$ (c) is subject to the provisions of 2 (a) said, "It is perfeetly clear that all three of these practices [practices forbidden by $\S \S 2(\mathrm{c})$, (d) and (e)] were forbidden because of their tendency to lessen competition and create monopoly, without regard to their effect in a particular case; and there is no reason to read into the sections forbidding them the limitations contained in Section 2(a) having relation to price discrimination which is an extremely difficult matter to deal with and is condemned as unfair only in those cases where it has an effect in suppressing competition or in tending to create monopoly." Id. at 766-767. The above quote was incorporated with approval into the decision in Great Atlantic \& Pacific Tea Co. v. FTC, supra note 144 at 677 .

147 Id. at 667 . In an appendix to the court's opinion affirming the FTC's order, the order itself is primted. Paragraph 3 reads: "[cease and desist from] [a]ccepting, and the policy and practice of accepting, on its purchase of commodities from sellers prices reflecting and all allowances and discounts representing brokerage savings effected by sellers on their sales of commodities to the respondent." (Emphasis added.) Id. at 679.

148 "Out of a total of 232 complaints under the Robinson-Patman Act issued to date, 103 have charged violation of subsection (c). Of the 137 cease and desist orders issued by the Commission under the Act, 76 derive force from the subsection." Austern, Section 2(c), CCH RosINSON-PATMAN SYMPOSTUM 37, 38 (1946). See excellent bibliographical classifications of $\$ 2(c)$ cases listed. Id. at 48-54. The article forecasted the settlement of many other cases based on the now decided Southgate Brokerage case discussed infra at note 163, et seq. Id. n.8. 
between. His income is derived from the sale of his services. When sellers hire his services (the normal situation) the broker's income represents a cost to the seller, and like all other seller costs, is reflected in the price the seller charges the buyer for the product. Brokers constitute the connecting link between buyers and sellers. To say that their services benefit sellers and not buyers is like saying the bottle in which milk is delivered benefits only the seller and not the buyer. Brokerage services, like the bottle, are a cost of distributing the product. But who is to furnish the bottle? Buyer furnished, the price of a unit of milk will be lower than if seller furmished. When furnished by neither, but instead by an independent bottle supplier, it seems to make little economic difference whether the seller or buyer pays the supplier directly.

Unlike bottles, brokerage cannot be furnished by the buyer, or at least if it is, he cannot legally be reconpensed for his efforts. Nor can an independent firm engaged by the buyer to furnish the seller with brokerage services receive payment for such services from the seller.

Biddle Purchasing Company sold its services under method 6 to both buyers and sellers. ${ }^{149}$ For its services to sellers, it charged a brokerage fee. ${ }^{150}$ For its services to buyer subscribers, it charged a service fee. ${ }^{151}$ Buyers contracting with sellers through Biddle paid sellers the same price for the product as did buyers purchasing through ordinary brokers, but Biddle credited or paid its subscribers the brokerage fees it received from sellers. ${ }^{152}$ Fourteen per cent of such subscribers received more in brokerage payments from Biddle than they paid to Biddle for service fees. ${ }^{153}$ The remainder of the subscribers either paid the same amount or more in service fees than they received in brokerage payments. Sellers had no economic interest in what Biddle did with the brokerage fees. They received equal prices froin all buyers, whether selling through Biddle or other brokers. The FTC found the arrangement in violation of Section 2(c) and its order forbidding any payment by sellers to Biddle intended to be paid over to Biddle's subscribers ${ }^{154}$ was upheld by the reviewing court. ${ }^{155}$ Biddle simply gambled that it would receive more in total service fees than it would receive in brokerage fees. It won with $86 \%$ of its subscribers. Subscribing buyers gambled that they would receive more in brokerage fees than they paid as subscribing fees. Only $14 \%$ of them won. Judge Swan, recognizing that only these latter $14 \%$ actually received their purchases at a lower net cost than purchasers buying through ordinary brokers, and believing a price discrimination is necessary to invalidate the arrangement, dissented with respect to that portion of the order prohibiting brokerage payments regardless of discrimination. ${ }^{156}$

149 Biddle Purchasing Co., 25 F.T.C. 564, 573 (1937).

$150 \mathrm{Ibid}$.

151 Id. at 574.

152 Id. at 575 .

153 Biddle Purchasing Co. v. FTC, supra note 144.

154 Supra note 149 at 578.

155 Biddle Purchasing Co. v. FTC, supra note 144.

150 Id. at 693. 
Subsequent cases reaffirmed the Biddle Rule. ${ }^{157}$ In Great Atlantic \& Pacific Tea Co. v. FTC, ${ }^{158}$ the reviewing court upheld a Commission order preventing the buyer from integrating backward by performing the brokerage function and thus receiving lower prices than buyers who bought through independent brokers. ${ }^{159}$ Whether it cost A \& $\mathrm{P}$ more to perform the brokerage function than it would have paid in higher cost prices for goods sold to them through independent brokers did not enter into the court's opinion. ${ }^{160}$ Injury to competition is not an element of a Section 2(c) violation. ${ }^{161}$

It is an empty argument to say, "Powerful buyers force sellers to grant them 'brokerage allowances' or lower prices in lieu of brokerage."102 Powerful buyers simply force sellers to grant lower prices. Their leverage consists of the obvious. Seller net return is the same in sales at lower prices to buyers furnishing the brokerage or "arranging" to have it furnished as it is in sales at higher prices through brokers engaged by the seller.

The Southgate case ${ }^{163}$ presented an interesting set of facts. The Southgate Brokerage Co. functioned as an ordinary broker under method 7(b) of the diagram with respect to $40 \%$ of its business. However, for the balance of its business Southgate assumed the role of a buyer for its own account (method 7(a)). It resold such purchases to wholesalers. On purchases made by Southgate for its own account, certain suppliers either charged Southgate a lower price than such suppliers quoted wholesalers or quoted the same price and rebated to Southgate an allowance. ${ }^{104}$ The differential in price or the allowance rebated was equal to the amount Southgate could have earned as a brokerage fee on sales which it brokered for the suppliers to wholesalers. The FTC characterized Southgate as a buyer receiving brokerage allowances on its own purchases and entered an order prohibiting the practice. ${ }^{105}$ The fourth circuit affirmed, ${ }^{100}$ terming the case "on all fours" with the $A \& P$ case. ${ }^{167}$ It is distinguishable. While A \& $\mathrm{P}$ was attempting integration of the retail and brokerage functions, Southgate, as a purchaser for its own account for resale to wholesalers, had secured for

$15 \mathrm{~T}$ See e.g., FTC v. Herzog \& Co., 150 F.2d 450 (2d Cir. 1945); Webb-Crawford Co. v. FTC, 109 F.2d 268 (5th Cir. 1940), cert. denied, 310 U.S. 638 (1940); Oliver Bros., Inc. v. FTC, supra note 144 .

158 Supra note 144.

15926 F.T.C. $486,513-514$ (1938).

160 Presumably A \& P's net cost of commodities purchased via this method was lower than the cost would be through traditional brokers. Otherwise, $A \& P$ would not have pursued it.

161 See note 146 supra.

162 H.R. REP. No. 2287, 74th Cong., 2d Sess. 15 (1936) wherein it is stated: "Among the prevalent modes of discrimination at which this bill is directed is the practice of certain large buyers to demand the allowance of brokerage direct to them upon their purchases, or its payment to an employee, agent, or corporate subsidiary whom they set up im the guise of a broker, and through whom they demand that sales to them be made."

163 Southgate Brokerage Co., 39 F.T.C. 166 (1944), enforced, 150 F.2d 607 (4th Cir. 1945), cert. denied, 326 U.S. 774 (1945).

164 See findings of FTC, id. at 168.

165 Id. at 170 .

166 Southgate Brokerage Co. v. FTC, 150 F.2d 607 (4th Cir. 1945).

167 "The Great Atlantic \& Pacific Tea case is practically on all fours . . . " Id. at 610 . 
itself a separate functional classification according to the FTC's own rules of classification. ${ }^{16 s}$ The differential between Southgate's cost price and wholesaler's cost price could be described as a trade discount. The argument seems not to have been made by Southgate or considered by the court or the FTC. ${ }^{169}$ When buyers operating as functional distributors seek trade discounts on purchases for their own account equal to the brokerage fees such buyers would have received had they brokered the goods to customers of their supplier, the Southgate rule will prohibit the discount by characterizing it as a brokerage allowance, illegal per se under Section 2(c).

Further cases interpreted the Section to prevent payment of brokerage by any seller to any broker if (1) any buyer of the goods has an economic interest in the broker, ${ }^{170}$ or, (2) if the broker has an economic interest in the buyer. ${ }^{171}$ The two clauses of the Section, "acting in fact for or in behalf, or is subject to the direct or indirect control," have proven elastic enough to allow the courts to reach some rather unrealistic results. In the WebbCrawford case, ${ }^{172}$ a circuit court, disagreeing with the FTC respecting whether the buyer controlled the broker or vice versa, nevertheless affirmed its order and held violative of Section 2 (c) payments by sellers to a brokerage firm, one of whose partners also owned a store buying from sellers using the services of the brokerage firm.

The net result of the section is to prevent any innovations in the distribution system relative to the brokerage function. Brokers, secure in their knowledge that those most interested in reducing brokerage fees ${ }^{173}$ are prevented from competing, are unlikely to be vigorous competitors among themselves.

Large chains, the avowed target of the Act, which have integrated to the manufacturer level, thus avoiding the Act, ${ }^{174}$ inust be secretly amused with the results of two recent Commission orders. Both in Carpel Frosted Foods ${ }^{175}$ and Independent Grocers Alliance Distributing Co., ${ }^{176}$ the FTC

108 Characterizing Southgate's position on the level of counpetition by the manner in which it sold goods would result in placing it in a separate functional classification sandwiched between suppliers and wholesalers, for it purchased from suppliers and sold to wholesalers.

169 The only new argument not raised by previous respondents charged with violation of $\$ 2$ (c) was that $\$ 2(d)$ authorized the allowances to Southgate since "service and facilities" were furnished by Southgate to the seller and \$2(d) requires sellers to make payment for such services on proportionally equal terms to all its customers. The court disposed of this argument by finding that the services involved were not rendered the seller. Southgate Brokerage Co., I50 F.2d at 611, supra note 163 .

170 See e.g., Quality Bakers of America v. FTC, 114 F.2d 393 (1st Cir. 1940) ; United Buyers Corp., 34 F.T.C. 87 (unappealed); FTC v. Herzog, supra note 157.

171 Supra note 157. Cf. Fitch v. Kentucky-Tenn. Light \& Power Co., 136 F.2d 12 (6th Cir. 1943) (buyer has treble damage action against seller for bribing buyer's agent).

1:2 Webb-Crawford Co. v. FTC, supra note 157. The court found that the buyer was controlled by the brokerage firm despite the fact that only one of the partners of the brokerage firm had any interest in the buyer. No brokerage payments as such reached the buyer.

173 Buyers, not sellers, would seem the most potent group to reduce broker fees. Sellers traditionally think of brokerage fees as they would think of sales taxes-charge them to the buyer and pay then to the broker.

174 Complete integration avoids the necessity of haggling with the FTC over what price you "charge" or "pay" yourself.

175 CCH Trade Reg. Rep. (9th ed.) II 14,878 (1952).

170 CCH Trade REg. ReP. (9th ed.) $\Uparrow 14,925.27$ (1952). 
found violations of Section 2(c) where separate legal entities formed by large groups of small retailers to act as intermediaries between sellers and themselves were paid brokerage, the benefits of which reached the retailers in the form of sales promotion plans, advertising, technological advice, etc. What is sauce for the goose is sauce for the gander, and though chains may originally have been the recipients of brokerage allowances, it clearly appears the FTC plans to play no favorites. This is as it should be. The loss to competition results from the section itself and not its equal application to all. Both chains and groups of small retailers should be allowed to supply competing brokerage services to sellers, rather than have artificial barriers created to their entry into the brokerage business.

Section 2(c) has never been used to prevent buyers paying sellers for brokerage services rendered the seller, though logically the section seems to forbid such a payment. ${ }^{17 \pi}$ The price buyers pay sellers includes an amount sufficient to reimburse the seller for brokerage fees which the seller pays for "hired brokerage services". Since indirect brokerage allowances in the form of lower prices to buyers performing brokerage services for the seller are condemned, indirect brokerage payments by buyers to sellers in the form of higher prices would seem equally invalid. Such a result would, of course, seriously jeopardize the position of the "independent" broker, and in view of the background of the Act, ${ }^{178}$ such an interpretation, despite its logical validity, is extremely unlikely. ${ }^{179}$

Little or no praise can be sung for Section 2(c).$^{180}$ Any value it may have in preventing unequal cost prices to buyers is far outweighed by its strangle hold on cost reducing distribution innovations.

\section{Functional Discounts and Method 8}

The FTC seems never to have discussed a situation involving three separate non-competing trade classifications between the original supplier and the consumer. ${ }^{181}$ In those cases in which facts indicate the supplier has created special classifications, such as promotional jobber ${ }^{182}$ or applicator, ${ }^{183}$ and granted those classifications a lower price than accorded other jobbers or wholesalers, the Commission has also found the special classifications in

177 The section is not limited in its language to a brokerage payment or allowance from seller to buyer but is framed in the general terms of "either to the other party." See note 140 supra.

178 See text discussion supra at note 37 where one of the special interest groups supporting the Act was shown to have been brokers.

179 See 51 HaRv. L. Rev. 1304 (1938).

$180 \mathrm{It}$ stands as the one section of the Act which has been almost universally criticized. See e.g., Adelman, supra note 8, at 54-56; Austern, supra note 148; Edwards, sucpra note 44, at 169; Oppenheim, supra note 133, at 1243-1246.

181 But compare the Southgate Brokerage case where the facts therein could easily have been so construed, stipra note 163.

182 American Art Clay Co., 38 F.T.C. 463 (1944).

183 Rubberoid Co. order to cease and desist, CCH Trade REg. REP. (9th ed.) $\| 14,313$ (1950). Cf. Miami Wholesale Drug Corp., 28 F.T.C. 485 (1939). 
competition with the other jobbers or wholesalers for retail trade and reached the same result as it did in Sherwin Williams. ${ }^{154}$

Assuming a supplier's scheme of distribution does include three separate non-competing trade classifications as indicated by method 8 of the diagram, the further assumption follows that trade discounts unjustified by cost savings would be allowed. ${ }^{185}$ Should the supplier, however, also adopt method 5 by selling direct to retailers, some problems of discount validity would arise. If the supplier's price to direct buying retailers is lower than the wholesaler's price to the jobber, an argument could be made that an extension of the rule of the Morton case ${ }^{186}$ (that suppliers are prohibited from selling to retailers at lower prices than to wholesalers whose customers compete with such retailers) would prohibit such a practice. The distinguishing feature, that the supplier in the instant situation does not control the wholesaler's price to the jobber, might not be sufficient reason for reaching an opposite result, since the price charged the wholesaler directly affects his resale price to the jobber.

Another problem similar to one in the Standard case ${ }^{18 T}$ would be presented should the jobber undercut the supplier's price to direct buying retailers. Whether the jobber's ability to undercut the supplier's price to direct buying retailers is caused by the price differential between the supplier's direct retail price and his wholesale price, or perhaps by the wholesaler's price to the jobber, might determine the original seller's liability for price discrimination. In this situation the original supplier, in order to avoid the charge of price discrimination, might have to control not only the wholesaler's price to jobbers, but also the jobber's price to retailers. ${ }^{188}$ Failure of the Commission to prohibit varying retailer cost prices resulting from buyers undercutting their supplier's direct prices to retailers, evidenced by their latest modification of the Standard order, ${ }^{189}$ may indicate its belief that the practice is not a violation of the Act. If so, this problem becomes moot. In that event, little would be left of the provision in the Act that price discrimination that "tends to injure, destroy, or prevent competition with [sellers, buyers] or with customers of either of them," is illegal since suppliers could undercut their wholesaler's resale prices and wholesalers could undercut their supplier's price to retailers.

The clause "to injure, destroy, or prevent competition ... with customers or either of them" would then mean, with one illogical exception, that customers of different wholesalers or retailers who paid varying prices resulting from the discriminatory prices charged those wholesalers or retailers by suppliers would be able to join the treble damage parade against the

184 See note 90 , supra.

185 This assumption is based on the further fact that all buyers at the same level of distribution were charged equal prices.

180 FTC v. Morton Salt Co., supra note 58 at 55.

187 F.T.C. at 58, supra note 100 . Modified order to cease and desist, $\$ 6$.

188 See the suggestion of the court that Standard could avoid price discrimination in this manner. Standard Oil v. FTC, 173 F.2d 217.

189 See note 110 , supra. 
suppliers. ${ }^{190}$ The exception is the Morton rule preventing the supplier from undercutting his customer's resale price below the price charged the customer himself.

\section{Conclusions}

1. The characterization of a price differential between two purchasers as a functional or trade discount accords it no cloak of immumty from the prohibitions of the Robinson-Patman Act.

2. Court and FTC interpretation of Section 2(c) of the Act has resulted in the per se invalidity of a type of functional discount.

3. Outlawing price discriminations which tend only to injure or destroy competitors rather than competition resnits from the rigid classifications of customers into single levels of distribution.

4. Basing point cases excepted, the present interpretation of the Act leaves wide open the possibility of price discrimination through the use of a single price policy to different trade classifications.

5. Paradoxically, the Act creates barriers to partial integration while at the same time inducing full integration.

6 . The error achieved by the economically incompatible marriage of prices to costs is further compounded by refusing recognition of an economic rather than an accounting meaning to the element of cost.

\section{Recommendations}

If economic price discrimination is the enemy to be destroyed, the Act needs serious revision. On the other hand, if one of the essentials of our present competitive system, that of varying buyer bargaining power, is to be retained, the Act also requires revision. Divergent aims require vastly opposite approaches.

Universal adoption of the FTC's theory of price discrimination in the basing point cases is vital to a program designed to outlaw economic price discriminations. The absence of a price differential is not synonomous with the absence of price discrimination. Product or service variation coupled with equal prices produces economic discrimination potentially as detrimental to competition as price variation for goods "of like grade or quality". The value judgnents necessary to match variations in price to variations in product-service exchanged undoubtedly would present serious problems of administration. However, if prevention of economic price discrimination is the "pot of gold", both the Act and its present interpretation is inconsistent and ineffective. Failure to allow buyers the exact economic cost savings resulting from their methods of purchasing would have to be prohibited. The sellers' present right to refuse to sell would have to be abrogated, for the exercise of such a right is the nltimate in economic price discrimination. The buyer is not offered the product at a higher price but is

190 See Gordon, The Meaning of Sections 1 and 3 in Conference Proceednas on Ronnvson-Patman Antr-Discrmmination Act 21, 30 (1936). Criticism of this view is expressed by Schniderman, supra note 14. 
refused it by the seller at any price. The traditions of the American economy, mcluding the right of customer selection and the principle that price is not determined alone by either accounting or economic concepts of cost, are too ingrained to expect any revision along these lines.

On the other hand, no one denies the imperfections of our present day economy when measured by the theoretical norms of competition. Legislation which tends to clog the attempts of buyers to match sellers' bargaming power enlarges those imperfections. The Robinson-Patman Act is a chief offender. Competition in the distributive system will continue to suffer as long as distributors are effectively prevented from competing across lines of commerce. Monopolizing or attempting to monopolize is already a crime, without Robinson-Patman. Amendment or enlightened interpretation would help; repeal is suggested. 